\title{
THE MICRO-SCALE MODELING BY EXPERIMENTAL STUDY IN PEM FUEL CELL
}

\author{
T. Taner ${ }^{1, *}$
}

\begin{abstract}
This study posed parameters effects to the PEM fuel cell performance by an experimental work. The aim of this study is to investigate performance effects of PEM fuel cells and to optimize water conditions as well as fuel cell performance. Platinum-plated catalyzed anode performance was demonstrated for the micro-scale modeling by experimental study in PEM fuel cell. Therefore, time dependent voltage and current parameter changes were observed for the performance analysis in the experimental study. PEM fuel cell was enhanced by adjusting the anode plate, air feed pump and hydrogen fuel quantities. This study is to determine about optimizing some parameters (pressure, flow rate, voltage) for the fuel cell performance. The result of this study was found to be $2.62 \times 10^{-7}[\mathrm{~kg} / \mathrm{s}]$ average of water production and generated $42.5[\mathrm{~kJ}] \mathrm{H}_{2}$ energy. In conclusion, performance efficiency was found to be around $52 \%$. These results demonstrated that water production was also very significant for the PEM fuel cell durability. PEM fuel cell energy efficiency increases while the mass flow is in a certain range and under pressure atmospheric conditions.
\end{abstract}

\section{Keywords: PEM Fuel Cell; Water Production; Hydrogen Gas; Performance; Energy Efficiency}

\section{INTRODUCTION}

The subject of this study is about enhancing PEM fuel cell by optimizing experiment parameters. Nowadays, the demand of alternative energy resources begins to increase due to the depletion of fossil fuels whereas the demand of PEM fuel cell, which increase by this way, is the one of the alternative energy resources. In this study, the performance of one of the innovative and alternative energy sources of Proton Exchange Membrane Fuel Cell (PEM) was researched for the micro-scale of fuel cell. The time-dependent voltage (volt) and current parameters for the performance analysis of $7 \mathrm{~W}$ power-operated $\mathrm{Pt}$ (platinum) catalyzed fuel cell in PEM fuel cells that have been investigated in this work. PEM fuel cell performance is experimentally measured by anode plate fuel cell. Because of these measurements, the effects of air and hydrogen feeding effects and performancebased optimizations were determined by experimental of single fuel cell. Effects of voltage and current performance are also identified by optimization of changing these parameters. Problem of PEM fuel cell is about durability and water management. Therefore, calculation of water production effects on energy efficiency of PEM fuel cell. This study indicated hydrogen gas and energy efficiency the micro-scale modeling by experimental study in PEM fuel cell.

Similar studies have been investigated because of literature review. Thus, this study has been done according to these literature studies, which are experimental works. One of the biggest problems of PEM the fuel cell is durability. PEM fuel cell can be used aircraft, automotive, aerospace vehicles and similar vehicles. These are likely to be crucial alternative energy sources for hydrogen fuel power, recycling energy systems and portable electronic devices [1, 2]. In these similar studies were conducted with PEM fuel cells. It can be seen that water management is a significant issue. PEM fuel cell performance needs to be adjusted water management in efficient way [3]. The inlet and outlet of the water carried in the PEM fuel cell. Performance of fuel cell was researched by theoretical and experimental [4]. Performance of fuel cell was seen separately from gas diffusion plates generally. Thus, it can be enhanced recovery and transport at lower flow rates [5].Fuel cell membrane (water) content and properties, parameter effects and ionic conductivity have been investigated in other study [6]. Entering hydrogen and oxygen gases to the fuel cell must be humid to increase the performance, so do chemical reaction [1]. Water management can be improved in anode working conditions [7]. Fuel cell performance that is improved by introducing more oxygen into the anodes according to the boundary operating conditions at the cathode with increasing inlet velocity and outlet pressure [8]. In this experimental study, the air stoichiometric ratio and performance effects of air-relative humidity of PEM fuel cells were investigated depending on the literature [2]. Water balance of fuel cell in cathode section was researched by another study. When using high-resolution neutron This paper was recommended for publication in revised form by Associate Editors of Editor-in-Chief Ozgen Acikgoz ${ }^{1}$ Department of Motor Vehicles and Transportation Technology, Aksaray University, Aksaray, TURKEY 
radiography in the direction of the plane with the anode, pressure and relative humidity gradients were shown in the fuel cell membrane electrode setup, where saturation profiles change in the diffusion medium [9]. The advantages and disadvantages of the fuel cell are also mentioned in this experimental work. In addition to the advantages of the PEM fuel cell, it also has disadvantages. PEM fuel cell has been found to be advantageous to operate at the electrode reaction kinetics, heat and water management, alternative catalysis, high power density and low operating temperature [10-17]. However, high sensitivity, membrane (membrane) and materials have been found to be very expensive in the PEM fuel cell. Many disadvantages can be seen such as gasification of fuel cell membrane durability materials, gas diffusion layer, disruption and manufacturing process difficulties $[10-11 ; 18$ 21]. The electric energy efficiency of PEM fuel cell was found about $40 \%$ in a previous study [22]. In the PEM fuel cell, it is possible to quickly remove the water by controlling it with the heat and efficiency of a high performance. When the proton $\mathrm{H}^{+}$is conveyed from anode to cathode correctly, the amount of evaporation is greater than the amount of water. This waste of water can increase efficiency of fuel cell. Apart from that, the PEM fuel cell has a durability problem due to high temperature $[17,23]$. This durability problem is the most critical feature of the PEM fuel cell. This problem can only be solved by water management. In this way, the problem of fuel cell durability can be eliminated. If this problem is resolved, the PEM fuel cell becomes an alternative energy source that provides significant energy $[17,24]$. If low-humidity conditions are met in the fuel cell, performance and efficiency rates will become effective [17, 25]. The reaction took place using the platinum and catalyst fuel cycle $[17,26]$. If the platinum value can be got high value, the performance can be decreased by this state $[17,27]$. On the contrary, fuel cell is one of the biggest advantages of high performance efficiencies and no emission value $[17,28]$. Parameters are temperature, current, and voltage that were about effects of PEM fuel cell performance [29-30]. Neutralized water transport method and flow were shown for PEM fuel cell cycle in another study [31]. The micro and macro scale transport processes were investigated to enhance PEM fuel cell performance [32]. Giurgea et al. [33] demonstrated flooding conditions, which were accomplished by rising the hygrometry of the inlet airflow at constant temperature of the fuel cell stack, or by reducing the temperature of the fuel cell stack at constant hygrometry of inlet airflow. Rezaee and Houshmand [34] posed an energy and exergy analysis of a combined power generation system consists of a PEM fuel cell power station. Gimba et al. [35] enhanced to research the effects of operating parameters such as temperature, anode and cathode pressures, reactants flow rates, membrane thickness, and humidity on the performance of the PEM fuel cell. Haghighi and Sharifhassan [36] studied about the exergy of a high temperature PEM fuel cell that was optimized for exergy efficiency and thermodynamic irreversibility. Similar studies researched about durability, water management and material properties. Many previous studies applied theoretical and experimental studies in PEM fuel cell performance analysis.

In this study, it has been found that water management needs to be applied well in order for the fuel cell to perform well. Electrolysis has attracted great interest as a hydrogen production method in PEM fuel cells. This study was focused on the mass flow that is in a certain range and under pressure atmospheric conditions. Therefore, a micro-scale of PEM fuel cell energy efficiency can increase remarkably. These parameters affect water waste and durability of PEM fuel cell. Thus, it is difficult to obtain energy from the PEM fuel cell. This study was aimed to investigate the performance of the PEM fuel cell experimentally, to optimize the mass airflow and the pressure, to enhance the current and voltage quantities and to provide well water management. When air mass flow rate and pressure changed, PEM fuel cell efficiency was optimized in this study. Due to these reasons, importance of this study is to improve the performance of PEM fuel cells and to enhance PEM fuel cell for future similar studies.

\section{MATERIAL and METHOD}

In this experimental study, using technical characteristics of the PEM fuel cell are given below;

- Micro-scale Anodic Plate Clear Pack single-cell fuel cell specifications: weight $520 \mathrm{~g}$, dimensions 110 x 90 x 70 $\mathrm{mm}$, electrical feature 2 gold -plated M4 brass screws, gas instant fittings $\varnothing 4 \mathrm{~mm}$ anode and $\varnothing 6 \mathrm{~mm}$ cathode, - MEA (Membrane Electrode Assembly) specifications: Nafion $25 \mu \mathrm{m}$ thick, active area of 50 x $50 \mathrm{~mm}$ and anode platinum loading is $0.3 \mathrm{mg} / \mathrm{cm}^{2}$,

- 0-2.5 bar hydrogen pressure regulator specifications: weight $180 \mathrm{~g}$, dimensions $65 \times 80 \times 80 \mathrm{~mm}$, accuracy is $+/$ $0.1 \mathrm{bar}$,

- Temperature of maximum internal is $70^{\circ} \mathrm{C}$, 
- Regulated air supply system (Air supply for providing an air mass) specifications: weight $600 \mathrm{~g}$, dimensions 170 x $60 \times 125 \mathrm{~mm}$, power supply is $24 \mathrm{~V} \mathrm{DC}$, range of use is 0 to $2 \mathrm{l} / \mathrm{min}$,

- Electronic load (Power supply) specifications: weight 920 g, dimensions $118 \times 123 \times 130 \mathrm{~mm}$, voltage control from $0.05 \mathrm{~V}$ to $5 \mathrm{~V}$, power is from $0 \mathrm{~W}$ to $20 \mathrm{~W}$ during 30 minutes, sample rate is $10 \mathrm{~Hz}$, power supply is $24 \mathrm{~V}$ $\mathrm{DC}$,

- Software is Labview for Pragma Industries' electronic load,

- Air discharge manual valve,

- Voltage-current-temperature control and tuning software for requiring operation,

- A 101 metal hydride tank ( $\varnothing 35 \times 130 \mathrm{~mm}$ dimensions and $470 \mathrm{~g}$ weight) with $99.9 \%$ pure hydrogen gas supplier was prepared.

In the experimental study, the 101 tube with hydrogen gas was prepared for testing by connecting to the pressure regulator and to the anodic plate fuel cell with the air feed pump and special polyurethane flexible pipes. The hydrogen gas metal tank valve was opened and the power supply operated. The fuel cell software was switched on and adjusted from the pressure regulator for the required differential pressures. The manual valve was opened for 5 to 10 seconds to remove the air remaining in the fuel cell for the anode section. In order to receive the data, data logging was opened and the electronic load was set at constant voltage. Afterwards the air flow was provided by the air supply pump with different air flow. The MEA (Membrane Electrode Assembly) was run for 15 minutes to allow the system to reach the equilibrium depending on the input moisture condition. The preparation of the test pressure and the airflow at different values were carried out following the following sequence:

1. Filling a pure hydrogen gas tank with a pressure of 400 bar at a pressure of 50 liter with the help of a hydrogen regulator in a 101 metal tank,

2. Connection of 101 metal tank with pure hydrogen gas via the pressure regulator in the fuel cell system,

3. Operation of the power source and the air-supplier pump respectively,

4. Manual valve opened to prevent excess air,

5. Obtaining voltage and current results.

\section{EXPERIMENTAL STUDIES AND METHODS} PEM Fuel Cell Operation

The 101 hydrogen hydride tank was connected to the fuel cell system via a polyurethane pipe to the pressure regulator. Afterwards, $7 \mathrm{~W}$ power supply and air provider pump was turned on. The manual valve was opened for 5 to 10 seconds to release the remaining air in the fuel cell and the remaining air was discharged. While the software was opened, data logging data was obtained at 15 minutes after the currents and voltages were obtained.

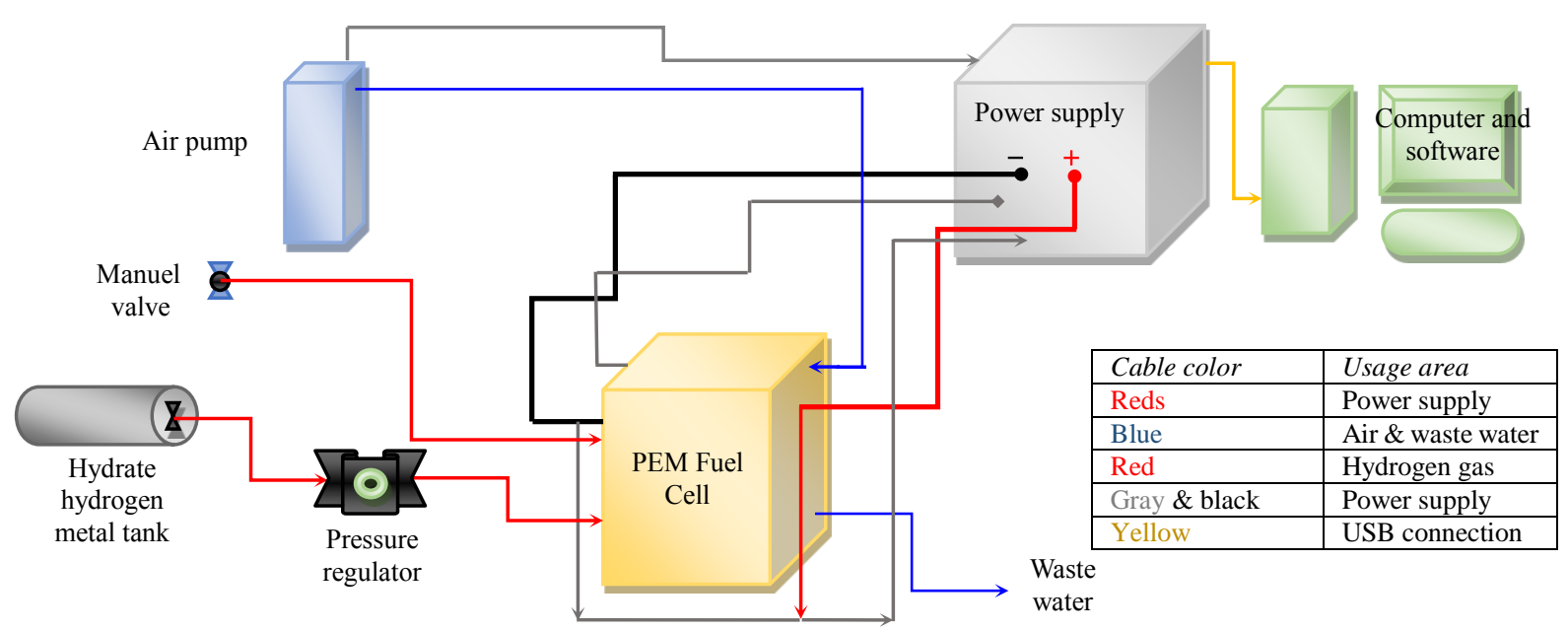

Figure 1. Schematic drawing of the PEM fuel cell in the experimental study 
The PEM fuel cell test set-up is detailed schematic drawing in Fig. 1. As a result of the literature study and preliminary tests, it is possible to operate the power supply for 15 minutes by adjusting the voltage of $1 \mathrm{Nm}$ fuel cell torque meter, $0.5-1$ bar pressure, $0.6-1 \mathrm{~V}$ with $0.2-0.41 / \mathrm{min}$ air mass flow rate in 15 minute.

\section{Investigation of Range in Voltage and Current Dependent Time}

During the PEM fuel cell experimental study, the fuel cell was tightened with a $1 \mathrm{Nm}$ torque meter adjuster. Firstly, the current and the changes in the tension are observed in Fig. 2 by adjusting the $0.6 \mathrm{~V}$ voltage with 0.5 bar pressure, $0.2 \mathrm{l} / \mathrm{min}$ air mass flow supply. Then parameters were changed and optimized as $1 \mathrm{~V}$ voltage with 1 bar pressure and 0.4 1/min air mass flow supply. Findings related to these values were discussed. In each second, voltage and current changes were obtained for 15 minutes. These experiments were repeated four times in order to get effective results.

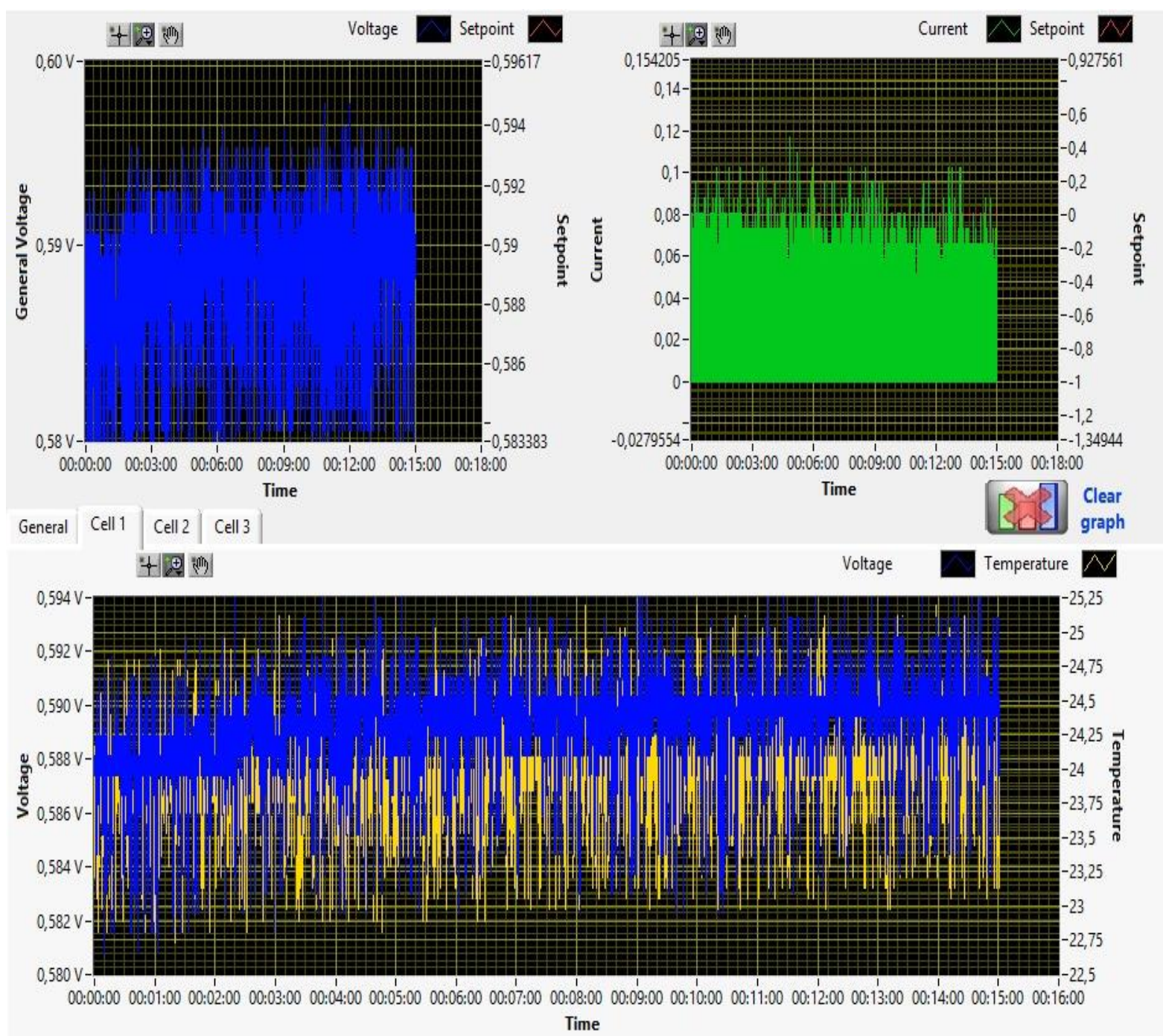

Figure 2. Software screen display of voltage, current and temperature graphs after 15 minutes of experiment [37]

\section{Calculation of PEM Fuel Cell Gas Consumption and Water Amount}

In the PEM fuel cell experimental work, the calculation of gas consumption and waste water volumes are crucial for fuel cell efficiency. The reaction between hydrogen and oxygen gas are as follows [17, 35-40]:

$$
\mathrm{H}_{2}+\frac{1}{2} \mathrm{O}_{2} \rightarrow \mathrm{H}_{2} \mathrm{O} \text { electric power }+ \text { waste heat (water) }
$$

The fuel cell anode reaction is as follows: 
The fuel cell cathode reaction is as follows:

$$
\frac{1}{2} \mathrm{O}_{2}+2 \mathrm{H}^{+}+2 \mathrm{e}^{-} \rightarrow \mathrm{H}_{2} \mathrm{O}
$$

The mass balance in the PEM fuel cell is as follows:

$$
\Sigma \mathrm{m}_{\text {in }}=\Sigma \mathrm{m}_{\text {out }}
$$

The formula that gives the relationship between the amount of gas used in the fuel cell and the current (electric charge) is as follows [35, 39, 41]:

$$
\mathrm{I}[\mathrm{A}]=2 \mathrm{~F}[\mathrm{C} / \mathrm{mol}] \times \mathrm{n}_{\mathrm{H} 2}[\mathrm{~mol}]
$$

In the experimental work, the current I notion is represented by the symbol [A], the Faraday constant $\mathrm{F}$ is 96485 [C / mol], and $\mathrm{n}$ is the molar ratio of hydrogen gas.

Since the experiment is carried out under the parameters of 2 types of voltage and current for 15 minutes, when the time is considered, the formula is as follows $[35,36,41]$ :

$$
\mathrm{I}[\mathrm{A} / \mathrm{s}]=2 \mathrm{~F}[\mathrm{C} / \mathrm{mol}] \times \mathrm{n}_{\mathrm{H} 2}[\mathrm{~mol} / \mathrm{s}]
$$

If molarity $\mathrm{n}_{\mathrm{H} 2}[\mathrm{~mol} / \mathrm{s}]$ is rearranged to find the consumption of hydrogen gas:

$$
\mathrm{n}_{\mathrm{H}_{2}}\left[\frac{\mathrm{mol}}{\mathrm{s}}\right]=\frac{\mathrm{I}\left[\frac{\mathrm{A}}{\mathrm{s}}\right]}{2 \mathrm{~F}\left[\frac{\mathrm{C}}{\mathrm{mol}}\right]}
$$

Similarly, the formula giving the amount of molarity oxygen gas $\mathrm{n}_{\mathrm{O}_{2}}[\mathrm{~mol} / \mathrm{s}]$ is given below:

$$
\mathrm{n}_{\mathrm{O}_{2}}\left[\frac{\mathrm{mol}}{\mathrm{s}}\right]=\frac{\mathrm{I}\left[\frac{\mathrm{A}}{\mathrm{A}}\right]}{4 \mathrm{~F}\left[\frac{\mathrm{C}}{\mathrm{mol}}\right]}
$$

Water molarity production amount $\mathrm{n}_{\mathrm{H}_{2} \mathrm{O}}[\mathrm{mol} / \mathrm{s}]$ can be calculated as follows:

$$
\mathrm{n}_{\mathrm{H}_{2} \mathrm{O}}\left[\frac{\mathrm{mol}}{\mathrm{s}}\right]=\frac{\mathrm{I}\left[\frac{\mathrm{A}}{\mathrm{s}}\right]}{2 \mathrm{~F}\left[\frac{\mathrm{C}}{\mathrm{mol}}\right]}
$$

Inlet of $\mathrm{O}_{2}$ and $\mathrm{H}_{2}$ mass flow amount can be calculated respectively as follows [36, 41]:

$$
\begin{gathered}
\dot{\mathrm{m}}_{\mathrm{O}_{2}}\left[\frac{\mathrm{kg}}{\mathrm{s}}\right]=3.57 \times 10^{-7}\left[\frac{\lambda_{\mathrm{st}} \times \mathrm{W}_{\text {net }}}{\mathrm{v}_{\text {cell }}}\right] \\
\dot{\mathrm{m}}_{\mathrm{H}_{2}}\left[\frac{\mathrm{kg}}{\mathrm{s}}\right]=1.05 \times 10^{-8}\left[\frac{\mathrm{W}_{\text {net }}}{\mathrm{v}_{\text {cell }}}\right]
\end{gathered}
$$

Oxygen stoichiometry rate can be defined as $\lambda_{\text {st }}$ symbol. Electric power is $\mathrm{W}_{\text {net }}[\mathrm{W}]$ and $\mathrm{V}_{\text {cell }}[\mathrm{V}]$ is voltage of the experiment. $\left[\frac{W_{\text {net }}}{V_{\text {cell }}}\right]$ can be equal to $I_{\text {cell }}$. An effective energy content of hydrogen fuel's specific enthalpy is assumed $1.43 \times 10^{8}[\mathrm{~J} / \mathrm{kg}]$. Lost hydrogen gas $\left(\mathrm{m}_{\mathrm{H}_{2, \text { lost }}}[\mathrm{kg}]\right)$ amount can be calculated during purge. If its purge amount is 30 for $0.5 \mathrm{~s}$ at around $200 \mathrm{ml} / \mathrm{s}$, lost hydrogen gas becomes 3 liter that is equal to $27 \times 10^{-5} \mathrm{~kg}$. 
Journal of Thermal Engineering, Research Article, Vol. 3, No. 6, Special Issue 6, pp. 1515-1526,

Total consuming hydrogen weight $\left(\mathrm{m}_{\mathrm{H}_{2, \text { total }}}[\mathrm{kg}]\right)$ can be found by collecting hydrogen gas mass flow $\left(\mathrm{m}_{\mathrm{H}_{2}}[\mathrm{~kg}]\right)$ with Lost hydrogen gas $\left(\mathrm{m}_{\mathrm{H}_{2} \text {,lost }}[\mathrm{kg}]\right)$ amount. Air stoichiometry rate $\lambda_{\text {air }}$ is 14,7 . Usage of air mass flow amount can be calculated as follows:

$$
\dot{\mathrm{m}}_{\text {air }}\left[\frac{\mathrm{kg}}{\mathrm{s}}\right]=8.29 \times 10^{-8}\left[\frac{\mathrm{W}_{\mathrm{net}}}{\mathrm{v}_{\text {cell }}}\right]
$$

Thus, amount of exit air mass flow can be calculated difference between inlet of $\mathrm{O}_{2}$ and usage of air mass flow amount as follows [36, 41]:

$$
\dot{\mathrm{m}}_{\text {air }} \text { exit }\left[\frac{\mathrm{kg}}{\mathrm{s}}\right]=\left\{3.57 \times 10^{-7}\left[\frac{\lambda_{\mathrm{st}} \times \mathrm{W}_{\text {net }}}{\mathrm{v}_{\text {cell }}}\right]\right\}-\left\{8.29 \times 10^{-8}\left[\frac{\mathrm{W}_{\text {net }}}{\mathrm{v}_{\text {cell }}}\right]\right\}
$$

Then, water production can be calculated as follows:

$$
\dot{\mathrm{m}}_{\mathrm{H}_{2} \mathrm{O}}\left[\frac{\mathrm{kg}}{\mathrm{s}}\right]=9.34 \times 10^{-8}\left[\frac{\mathrm{W}_{\text {net }}}{\mathrm{v}_{\text {cell }}}\right]
$$

In addition, cell efficiency can be determined as follows:

$$
\eta_{\text {cell }}=\frac{\mathrm{v}_{\text {cell }}}{1.48}
$$

Production of heat $\mathrm{Q}_{\mathrm{H}}[\mathrm{W}]$ that is generated from PEM fuel cell can be calculated in regard to electric power as follows [41]:

$$
\dot{\mathrm{Q}}_{\mathrm{H}}=\mathrm{W}_{\text {net }}\left(\frac{1.25}{\mathrm{~V}_{\text {cell }}}-1\right)
$$

Generation of energy can be calculated via 900 seconds as follows:

$$
\mathrm{E}[\mathrm{J}]=\mathrm{W}_{\text {net }}[\mathrm{W}] \mathrm{xt}[\mathrm{s}]
$$

Amount of energy account for hydrogen gas can be calculated as follows:

$$
\mathrm{E}_{\mathrm{H}_{2}}[\mathrm{~J}]=\mathrm{m}_{\mathrm{H}_{2, \text { total }}}[\mathrm{kg}] \times 1.43 \times 10^{8}\left[\frac{\mathrm{J}}{\mathrm{kg}}\right]
$$

Energy efficiency of PEM fuel cell can be found from Eq. 17 and 18 as follows:

$$
\eta_{\mathrm{en}}=\frac{\mathrm{E}[\mathrm{J}]}{\mathrm{E}_{\mathrm{H}_{2}}[\mathrm{~J}]}
$$

Hydrogen gas stoichiometry rate $\left(\lambda_{\mathrm{H}_{2}}\right)$ can be can be calculated as follows:

$$
\lambda_{\mathrm{H}_{2}}=\frac{\mathrm{m}_{\mathrm{H}_{2, \text { total }}[\mathrm{kg}]}}{\mathrm{m}_{\mathrm{H}_{2}}[\mathrm{~kg}]}
$$

In addition, Energy efficiency of PEM fuel cell can be calculated as follows:

$$
\eta_{\mathrm{en}}=\frac{\mathrm{V}_{\text {cell }}[\mathrm{J}]}{1.48} \times \frac{1}{\lambda_{\mathrm{H}_{2}}}
$$

Eq. 19 and Eq. 20 can validate their results. 


\section{RESULTS AND DISCUSSION}

Experimental studies were completed as 0.6 Volt with 0.5 bar pressure, $0.2 \mathrm{l} / \mathrm{min}$ air mass flow and 1.0 Volt with 1.0 bar pressure, $0.4 \mathrm{l} / \mathrm{min}$ air mass flow for 15 minutes. Then, these results were compared each other by PEM fuel cell gas consumption, production of water and energy efficiency. In addition, finding these results were drawn via voltage and current relations.

\section{Drawing of Voltage and Current Graphs}

In Fig. 3, operating the flow rate of the PEM fuel cell for 15 minutes was set at 0.6 Volt with 0.5 bar pressure, $0.2 \mathrm{l} / \mathrm{min}$ air mass flow for a time dependent. It has been found that the current changed logarithmic between $0.047 \mathrm{~A}$ and $0.029 \mathrm{~A}$, and the voltage range from $0.5867 \mathrm{~V}$ to $0.5888 \mathrm{~V}$.

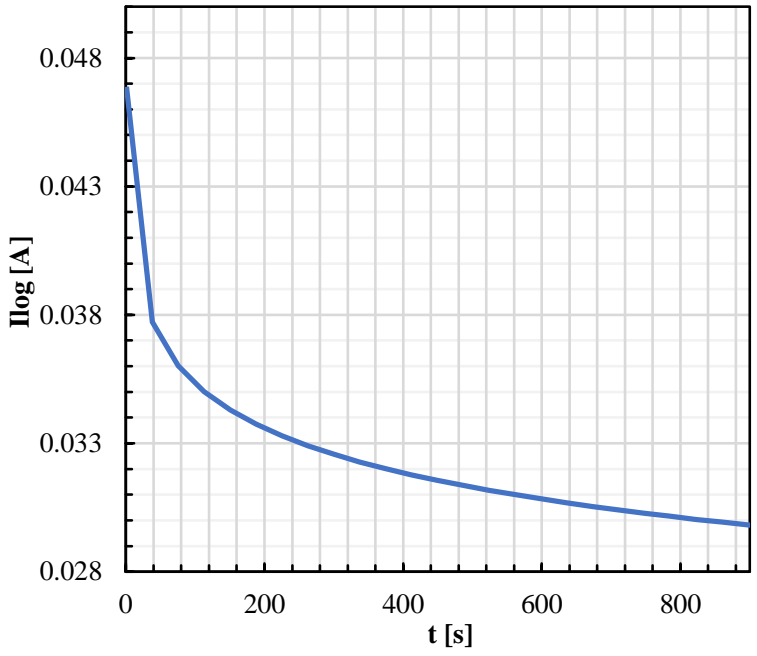

(a)

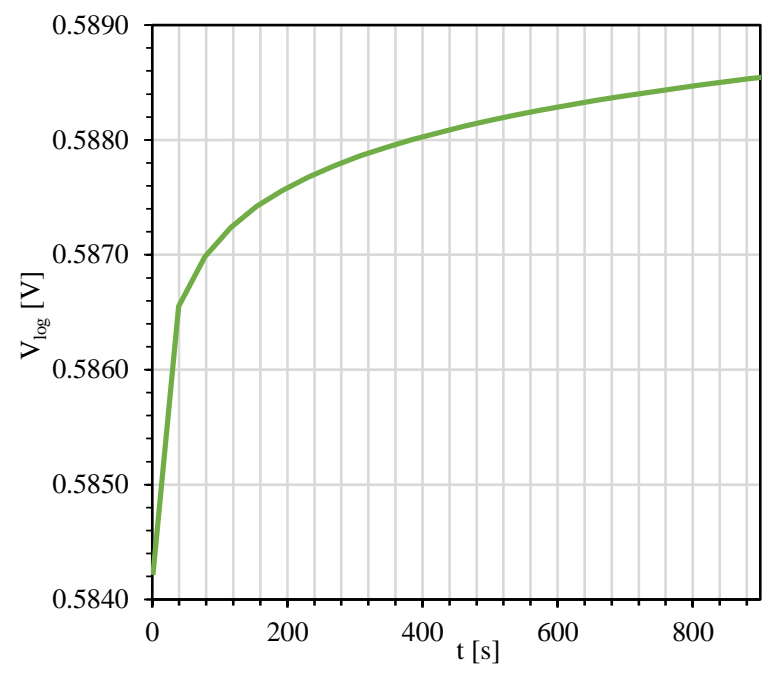

(b)

Figure 3. 0.5 bar pressure, $0.2 \mathrm{l} / \mathrm{min}$ air flow mass and $0.6 \mathrm{~V}$ voltage logarithmic changes of current and voltage with time

According to the same experimental study, 1.0 bar pressure, $0.4 \mathrm{l} / \mathrm{min}$ air flow feed, $1.0 \mathrm{~V}$ voltage was set and the flow in the PEM fuel cell operating for 15 minutes reached the values depending on the time. The current was found logarithmic to vary from $0.0556 \mathrm{~A}$ to $0.068 \mathrm{~A}$, and from $0.755 \mathrm{~V}$ to $0.785 \mathrm{~V}$ in Fig. 4 .

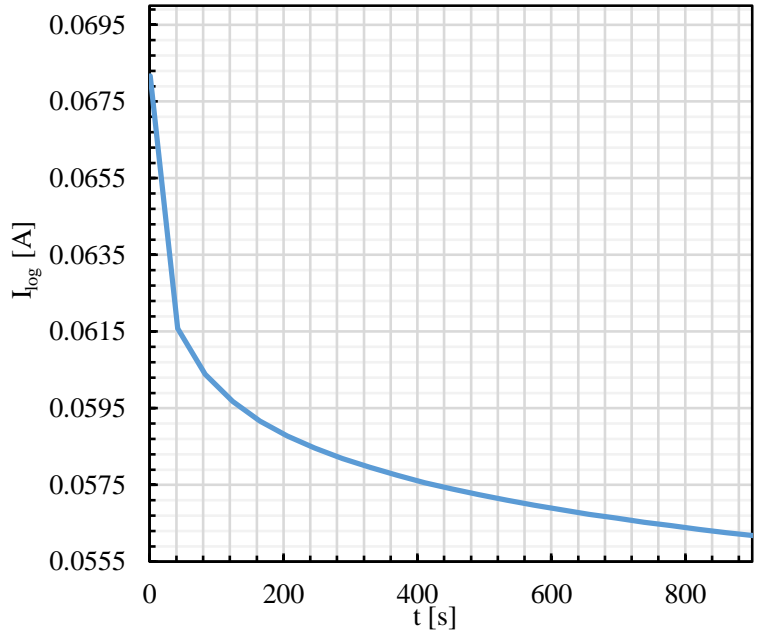

(a)

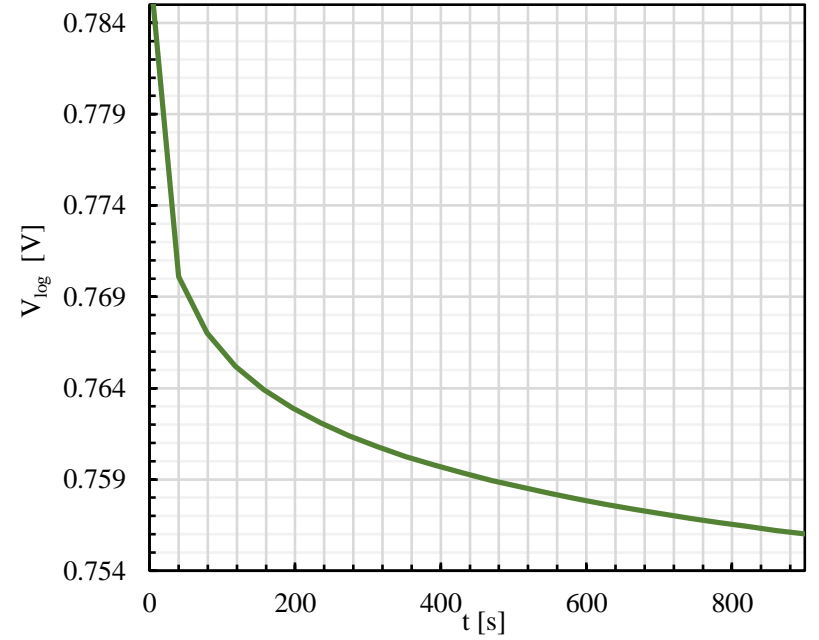

(b)

Figure 4. 1.0 bar pressure, $0.4 \mathrm{l} / \mathrm{min}$ air flow mass and $1.0 \mathrm{~V}$ voltage logarithmic changes of current and voltage with time 
In Table 1, the maximum and minimum changes in the fuel cell voltage and current parameters of the experimental data were given as follows: Operating PEM fuel cell for 15 minutes at 1.0 bar pressure, $1.0 \mathrm{l} / \mathrm{min}$ with $0.4 \mathrm{l} / \mathrm{min}$ air flow feed, according to experimental actual measurements; It was found that the voltage value dropped from $0.852[\mathrm{~V}]$ to $0.810[\mathrm{~V}]$ and the current value increased to 2.75 [A] from 2.87 [A] (set point approximately 1.9). PEM fuel cell operating for 15 minutes with a 0.5 bar pressure, $0.2 \mathrm{l} / \mathrm{min}$ airflow feed and 0.6 $\mathrm{V}$ voltage adjustment, according to experimental actual measurements; It was found that the voltage value increased from $0.588[\mathrm{~V}]$ to $0.590[\mathrm{~V}]$ and the current value decreased from 2.28 [A] from 2.23 [A] (set point approximately 1.9).

Table 1. PEM fuel cell parameters of the experimental work

\begin{tabular}{|c|c|c|c|c|}
\hline \multirow{2}{*}{ Experimental parameter variations } & \multicolumn{2}{|c|}{$\mathbf{V}_{\text {cell }}[\mathrm{V}]$} & \multicolumn{2}{|c|}{ I $[\mathbf{A}]$} \\
\hline & Max. & Min. & Max. & Min. \\
\hline \multirow{3}{*}{1.0 bar pressure, $0.4 \mathrm{l} / \mathrm{min}$ air mass flow rate $1.0 \mathrm{~V}$ voltage } & 0.852 & 0.810 & 2.87 & 2.75 \\
\hline & \multicolumn{2}{|c|}{ Average [V] } & \multicolumn{2}{|c|}{ Average $[\mathbf{A}]$} \\
\hline & \multicolumn{2}{|c|}{0.831} & \multicolumn{2}{|c|}{2.81} \\
\hline \multirow{4}{*}{0.5 bar pressure, $0.2 \mathrm{l} / \mathrm{min}$ air mass flow rate $0.6 \mathrm{~V}$ voltage } & Max. & Min. & Max. & Min. \\
\hline & 0.590 & 0.588 & 2.28 & 2.23 \\
\hline & \multicolumn{2}{|c|}{ Average [V] } & \multicolumn{2}{|c|}{ Average $[\mathbf{A}]$} \\
\hline & \multicolumn{2}{|c|}{0.589} & \multicolumn{2}{|c|}{2.255} \\
\hline
\end{tabular}

\section{Gas Consumption Amounts and Water Production of PEM Fuel Cell}

In this study, gas consumption and water production were calculated from Eq. 5 to Eq. 14, respectively. Eventually, these results were found and given in Table 2. Total consumption of hydrogen gas weight average was found $2,966 \times 10^{-4}[\mathrm{~kg}]$ according to 1.0 bar pressure, $0.41 / \mathrm{min}$ air mass flow rate $1.0 \mathrm{~V}$ voltage and 2,913 $\times 10^{-4}$ $[\mathrm{kg}]$ according to 0.5 bar pressure, $0.2 \mathrm{l} / \mathrm{min}$ air mass flow rate $0.6 \mathrm{~V}$ voltage. These results show that total total consumption of hydrogen gas weight is related to pressure, air mass flow and voltage in the experimental study. Beside, water production amount was investigated that water amount can change with air mass flow rate. Whereas 1.0 bar pressure, $0.4 \mathrm{l} / \mathrm{min}$ air mass flow rate $1.0 \mathrm{~V}$ voltage produced $2.62 \times 10^{-7}[\mathrm{~kg} / \mathrm{s}]$ average of water production, 0.5 bar pressure, $0.2 \mathrm{l} / \mathrm{min}$ air mass flow rate $0.6 \mathrm{~V}$ voltage produced $2.11 \times 10^{-7}[\mathrm{~kg} / \mathrm{s}]$ average of water production. These results posed that increasing air mass flow and voltage lead to generate water in the system.

Table 2. The result of the PEM fuel cell gas consumption amounts and water production

\begin{tabular}{|c|c|c|c|c|c|c|}
\hline Experiment & Value & $\dot{\mathbf{m}}_{\text {airexit }}[\mathrm{kg} / \mathrm{s}]$ & $\dot{\mathbf{m}}_{\text {water }}[\mathrm{kg} / \mathrm{s}]$ & $\dot{\mathrm{m} H} \mathrm{H}_{2}[\mathrm{~kg} / \mathrm{s}]$ & $\mathrm{mH}_{2}[\mathrm{~kg}]$ & $\mathbf{m H}_{2, \text { total }}[\mathrm{kg}]$ \\
\hline 1.0 bar pressure, 0.4 & Max. & $1.48 \times 10^{-5}$ & $2.68 \times 10^{-7}$ & $3.01 \times 10^{-8}$ & $2.71 \times 10^{-5}$ & $2.971 \times 10^{-4}$ \\
\hline $1 /$ min air mass flow & Min. & $1.42 \times 10^{-5}$ & $2.57 \times 10^{-7}$ & $2.89 \times 10^{-8}$ & $2.60 \times 10^{-5}$ & $2.960 \times 10^{-4}$ \\
\hline rate $1.0 \mathrm{~V}$ voltage & Avg. & $1.45 \times 10^{-5}$ & $2.62 \times 10^{-7}$ & $2.95 \times 10^{-8}$ & $2.66 \times 10^{-5}$ & $2.966 \times 10^{-4}$ \\
\hline 0.5 bar pressure, 0.2 & Max. & $1.18 \times 10^{-5}$ & $2.13 \times 10^{-7}$ & $2.39 \times 10^{-8}$ & $2.15 \times 10^{-5}$ & $2.915 \times 10^{-4}$ \\
\hline $1 / \mathrm{min}$ air mass flow & Min. & $1.15 \times 10^{-5}$ & $2.08 \times 10^{-7}$ & $2.34 \times 10^{-8}$ & $2.11 \times 10^{-5}$ & $2.911 \times 10^{-4}$ \\
\hline rate $0.6 \mathrm{~V}$ voltage & Avg. & $1.16 \times 10^{-5}$ & $2.11 \times 10^{-7}$ & $2.37 \times 10^{-8}$ & $2.13 \times 10^{-5}$ & $2.913 \times 10^{-4}$ \\
\hline
\end{tabular}

Table 3. The result of the PEM fuel cell energy efficiency

\begin{tabular}{ccccccccc}
\hline Experiment & Value & $\mathbf{W}_{\text {net }}[\mathbf{W}]$ & $\mathbf{E n ~ [ J ]}$ & $\mathbf{E n}_{\mathbf{H}_{2}}[\mathbf{J}]$ & $\boldsymbol{\lambda}_{\mathbf{H}_{2}}[\mathbf{\%}]$ & $\mathbf{Q}_{\mathbf{H}}[\mathbf{W}]$ & $\eta_{\text {en,el }}[\mathbf{\%}]$ & $\boldsymbol{\eta}_{\text {en, } \mathbf{H}_{2}}[\mathbf{\%}]$ \\
\hline 1.0 bar pressure, 0.4 & Max. & 2.445 & 2200.72 & 42488.37 & 10.96 & 1.14 & $52 \%$ & $53 \%$ \\
1/min air mass flow & Min. & 2.228 & 2004.75 & 42326.21 & 11.39 & 1.21 & $47 \%$ & $48 \%$ \\
rate 1.0 V voltage & Avg. & 2.335 & 2101.60 & 42407.29 & 11.17 & 1.18 & $50 \%$ & $50 \%$ \\
\hline 0.5 bar pressure, 0.2 & Max. & 1.345 & 1210.68 & 41691.08 & 13.53 & 1.51 & $29 \%$ & $29 \%$ \\
1/min air mass flow & Min. & 1.311 & 1180.12 & 41623.51 & 13.81 & 1.48 & $28 \%$ & $29 \%$ \\
rate 0.6 V voltage & Avg. & 1.328 & 1195.38 & 41657.29 & 13.67 & 1.49 & $29 \%$ & $29 \%$ \\
\hline
\end{tabular}

Note: PEM fuel cell is lower than the theoretical one due to the losses that occur during purge, which reduces the amount of available hydrogen gas. Therefore, the results were estimated to be due to the measurement of mathematical autonomy in 10 seconds according to polarization curve [37]. Enthalpy $\mathrm{H}_{2}$ was taken $1.0 \times 10^{8}$ $[\mathrm{J} / \mathrm{kg}]$ from study of Larmine and Dick [41]. 
In Table 3, the result of the PEM fuel cell energy efficiency and the other parameters were shown microscale voltage of PEM fuel cell. In these results, generation of hydrogen energy average amount was found 42.5 $[\mathrm{kJ}]$ according to 1.0 bar pressure, $0.4 \mathrm{l} / \mathrm{min}$ air mass flow rate $1.0 \mathrm{~V}$ voltage for the small scale of PEM fuel cell. Heating loss of fuel cell was found to 1.14-1.49 [W].

In this study, average performance efficiency was found to around $52 \%$ for the microscale of PEM fuel cell. These results were compared previous studies that posed similar results. Gimba et al. [35] calculated energy and exergy efficiency $48 \%$. Dincer and Rosen [38] posed that the maximum system energy and exergy efficiencies can be $42.3 \%$ and $49.6 \%$. Purnima and Jayanti [42] indicated energy efficiency $48.47 \%$. Tsai and Chen [43] determined energy efficiency $44 \%$. The PEM alone system operating at high pressure was calculated energy efficiency as $49.1 \%$ by Ferrero and Massimo Santarelli [44]. Salemme et al. [45] determined the highest and lowest value corresponding to methane (49.3\%) and acetylene $(42.6 \%)$, respectively. It can be seen that the result of this study energy efficiency is appropriate according to previous studies.

\section{CONCLUSION}

In conclusion, energy efficiency was found $52 \%$ for the microscale of PEM fuel cell in this study. This result was figured out for 1.0 bar pressure, $0.4 \mathrm{l} / \mathrm{min}$ air mass flow rate $1.0 \mathrm{~V}$ voltage. According to the results, when pressure, air mass flow rate and voltage were increased slowly, energy efficiency could rise up in effectively. In the future, similar experimental studies can be researched for optimization of the pressure, air mass flow rate and voltage for energy efficiency.

The results of this experimental study emphasized the durability of water management in terms of PEM fuel cell. Provided that production water quantity is plummeted by optimisation, PEM fuel cell lifetime can go up by the cell durability feature as well as energy efficiency.

Altering pressure, flow rate, voltage can adjust PEM fuel cell performance for the micro-scale of PEM fuel cell.

This study posed the performance of PEM Fuel Cell that can be increased by these parameters. If air supply can control in PEM Fuel cell, waste water will be managed easily in the system.

This experimental work will encourage other similar studies to improve the small scale of PEM fuel cell types.

In addition, it was observed that hydrogen gas energy efficiency results were very consistent when compared to previous studies. This study indicated that the temperature of the power supply declined as the voltage was increased.

As a scientific contribution, it is determined that the fuel cell energy efficiency increases while the mass flow is in a certain range and under pressure atmospheric conditions.

\section{ACKNOWLEDGEMENT}

I would like to thank the Aksaray University Scientific Research Projects Agency for supporting this project under the 2016-030 project.

\section{NOMENCLATURE}

Symbols and Units

$\dot{\mathrm{m}}_{\text {air }}$ exit Amount of exit air mass flow, $\mathrm{kg} / \mathrm{s}$

$\dot{\mathrm{m}}_{\text {air }} \quad$ Usage of air mass flow amount, $\mathrm{kg} / \mathrm{s}$

$\dot{\mathrm{m}}_{\mathrm{H}_{2}} \quad$ Inlet of hydrogen gas mass flow amount, $\mathrm{kg} / \mathrm{s}$

$\dot{\mathrm{m}}_{\mathrm{H}_{2} \mathrm{O}} \quad$ Water mass flow amount, $\mathrm{kg} / \mathrm{s}$

$\dot{\mathrm{m}}_{\mathrm{O}_{2}} \quad$ Inlet of oxygen gas mass flow amount, $\mathrm{kg} / \mathrm{s}$

$\mathrm{E}_{\mathrm{H}_{2}} \quad$ Amount of energy account for hydrogen gas, $\mathrm{J}$

$\mathrm{m}_{\mathrm{H}_{2, \text { lost }}} \quad$ Lost hydrogen gas amount, $\mathrm{kg}$

$\mathrm{m}_{\mathrm{H}_{2, \text { total }}}$ Total consuming hydrogen weight, $\mathrm{kg}$

$\mathrm{m}_{\mathrm{H}_{2}} \quad$ Hydrogen gas mass flow, $\mathrm{kg}$

$\mathrm{n}_{\mathrm{H}_{2} \mathrm{O}} \quad$ Water molarity production, $\mathrm{mol} / \mathrm{s}$ 
Journal of Thermal Engineering, Research Article, Vol. 3, No. 6, Special Issue 6, pp. 1515-1526,

December, 2017

$\begin{array}{ll}\mathrm{n}_{\mathrm{O}_{2}} & \text { Oxygen gas molarity, mol/s } \\ \eta_{\text {cell }} & \text { Cell performance, } \% \\ \eta_{\mathrm{en}} & \text { Energy efficiency, } \% \\ \mathrm{E} & \text { Amount of energy, } \mathrm{J} \\ \mathrm{F} & \text { Faraday constant, } \mathrm{C} / \mathrm{mol} \\ \mathrm{I} & \text { Current, } \mathrm{A} \\ \mathrm{m}_{\text {in }} & \text { Inlet mass, } \mathrm{kg} \\ \mathrm{m}_{\text {out }} & \text { Outlet mass, } \mathrm{kg} \\ \mathrm{n}_{\mathrm{H} 2} & \text { Hydrogen gas molarity, mol/s } \\ \mathrm{Q}_{\mathrm{H}} & \text { Production of heat, } \mathrm{W} \\ \mathrm{V}_{\text {cell }} & \text { Tension of fuel cell, } \mathrm{V} \\ \mathrm{W}_{\text {net }} & \text { Electric power, W } \\ \lambda_{\text {air }} & \text { Air stoichiometry rate } \\ \lambda_{\mathrm{H}_{2}} & \text { Hydrogen gas stoichiometry rate } \\ \lambda_{\text {st }} & \text { Stoichiometry rate }\end{array}$

\begin{tabular}{ll}
\multicolumn{2}{l}{ Abbreviations } \\
$\Sigma$ & Sum \\
$\mathrm{H}_{2}$ & Hydrogen gas \\
$\mathrm{O}_{2}$ & Oxygen gas \\
$\mathrm{A}$ & Ampere \\
$\mathrm{C}$ & Coulomb \\
$\mathrm{e}^{-}$ & Electron \\
$\mathrm{H}^{+}$ & Proton hydrogen ion \\
$\mathrm{H}_{2} \mathrm{O}$ & Dihydrogen monooxygen \\
$\mathrm{J}$ & Joule \\
$\mathrm{l}$ & liter \\
min & Minute \\
mol & molarity \\
$\mathrm{PEM}$ & Proton Exchange Membrane \\
$\mathrm{s}$ & Seconds \\
$\mathrm{t}$ & Time, $\mathrm{s}$ \\
$\mathrm{V}$ & Voltage \\
$\mathrm{W}$ & Watt
\end{tabular}

\section{REFERENCES}

[1] Huang, X., Reifsnider, K., "Modern aspects of electrochemistry 49: Durability of PEM fuel cell", 1-42, Springer, London (2010)

[2] Emery M., Frey M., Guerra M., Haugen G., Hintzer K., Lochhaas K. H., Pham P., Pierpont D., Schaberg M., Thaler A., Yandratis M., and Hamrock S., "Proton exchange membrane fuel cell 7: The development of new membranes for proton exchange membrane fuel cell”, ESC Transactions, Volume 11, Issue 1: 3-14 (2007)

[3] Arbabi F., Roshandel R., Karimi Moghaddam G., "Numerical modeling of an innovative bipolar plate design based on the leaf venation patterns for PEM fuel cells", IJE Transactions C: Aspects, Volume 25, No 3: 177 186, (2012)

[4] Zhang F. Y., Yang X. G., Wang C. Y., "Liquid water removal from a polymer electrolyte fuel cell”, Journal Electrochemical, 153, 2: 225-232, (2006)

[5] Zhang F. Y., Advani S. G., Prasad A. K., "Performance of a metallic gas diffusion layer for PEM fuel cells", Journal of Power Sources, Volume 176, Issue 1, 293-298, (2008)

[6] Dokkar B., Settou N., Imine O., Negrou B., Saifi N., Chennouf N., "Simulation of water management in the membrane of PEM fuel cell", EFEEA'10 International Symposium on Environment Friendly Energies in Electrical Applications, Ghardaia, Algeria, 1-4, (2010)

[7] Bao C., Ouyang M., Y1 B., "Analysis of water management in proton exchange membrane fuel cells", 
Tsinghua Science and Technology, 11 1: 54-64, (2006)

[8] Ekiz A., Camcı T., Türkmen İ., Sankır M., Uslu S., Baker D. K., Ağar E., "PEM tipi yakıt pilleri için çift kutuplu akış plakalarının modellenmesi”, Gazi Üniversitesi Mühendislik ve Mimarlık Fakültesi Dergisi, 26, 3: 591-605, (2011)

[9] La Manna J. M., Chakraborty S., Zhang F. Y., Mench M., Gagliardo J., and Owejan J., "Isolation of transport mechanisms in PEFCs with high resolution neutron imaging", Electrochemical Society ECS Transactions, 41, 1: 329-336, (2011)

[10] Andujar J.M., Segura F., "Fuel cells: History and updating. A walk along two centuries", Renewable and Sustainable Energy Reviews 13: 2309-2322, (2009)

[11] Chandan A., Hattenberger M., El-kharouf A., Du S., Dhir A., Self V., Pollet B. G., Ingram A., Bujalski W., "High temperature HT polymer electrolyte membrane fuel cells PEMFC - A review", Journal of Power Sources 231: 264-278, (2013)

[12] Asensio J.A., Sanchez E.M., Gomez-Romero P., "Proton-Conducting Membranes Based on Benzimidazole Polymers for High-Temperature PEM Fuel Cells", Chemical Society Reviews 39: 3210-3239, (2010)

[13] Devanathan R., "Recent developments in proton exchange membranes for fuel cells", Energy \& Environmental Science 1: 101-119, (2008)

[14] Rikukawa M., Sanui K., "Proton-conducting polymer electrolyte membranes based on hydrocarbon polymers", Progress in Polymer Science 25: 1463-1502, (2000)

[15] Neelakandan S., Rana D., Matsuura T., Muthumeenal A., Kanagaraj P., Nagendran A., "Fabrication and electrochemical properties of surface modified sulfonated poly vinylidenefluoride-co-hexafluoropropylene membranes for DMFC application", Solid State Ionics 268: 35-41, (2014)

[16] Li J., Wang J., Chen X., Lv Z., Chen T., Wang T., "A highly conductive proton exchange membrane for high temperature fuel cells based on poly5-vinyl tetrazole and sulfonated polystyrene", Solid State Ionics 255: 128-134, (2014)

[17] Taner T., "Alternative Energy of the Future: A Technical Note of PEM Fuel Cell Water Management", Journal of Fundamentals of Renewable Energy and Applications 5, 3: 1-4, (2015)

[18] Larminie J., Dicks A., "Fuel Cell Systems Explained", John Wiley \& Sons Ltd., West Sussex. ISBN: 0-47084857-X, (2003).

[19] Li Q., He R., Jensen J.O., Bjerrum N.J., "Approaches and recent development of polymer electrolyte membranes for fuel cells operating above $100^{\circ} \mathrm{C}$ ", Chemistry of Materials 15: 4896-4915, (2003)

[20] Villers D., Jacques-Bedard X., Dodelet J.P., "Fe-Based catalysts for oxygen reduction in PEM fuel cells pretreatment of the carbon support", Journal of the Electrochemical Society 151, A1507-A1515, (2004).

[21] Oh H.-S., Oh J.-G., Roh B., Hwang I., Kim., "Development of highly active and stable non-precious oxygen reduction catalysts for PEM fuel cells using polypyrrole and a chelating agent", Electrochemistry Communications 13: 879-881, (2011)

[22] Mekhilefa S., Saidurb R., Safari A., "Comparative study of different fuel cell technologies", Renewable and Sustainable Energy Reviews 16: 981- 989, (2012)

[23] Kim M., Kang T., Kim J., Young-Jun Sohn., "One-dimensional modeling and analysis for performance degradation of high temperature proton exchange membrane fuel cell using PA doped PBI membrane", Solid State Ionics 262: 319-323, (2014)

[24] Attaran A. M., Javanbakht M., Hooshyari K., Enhessari M., "New proton conducting nanocomposite membranes based on poly vinyl alcohol/poly vinyl pyrrolidone/BaZrO3 for proton exchange membrane fuel cells", Solid State Ionics 269: 98-105, (2015)

[25] Jiang S. P., "Functionalized mesoporous materials as new class high temperature proton exchange membranes for fuel cells", Solid State Ionics 262: 307-312, (2014)

[26] Choi H-J., Jung S-M., Seo J-M., Chang D.W., Dai L., Baek J-B., “Graphene for energy conversion and storage in fuel cells and super capacitors", Nano Energy 1, 534-551, (2012)

[27] Tiwari J. N., Tiwari R. N., Singh G., Kim K. S., "Recent progress in the development of anode and cathode catalysts for direct methanol fuel cells", Nano Energy 2: 553-578, (2013)

[28] Higgins D. C., Wang R., Hoque Md. A., Zamani P., Abureden S., Chen Z., "Morphology and composition controlled platinum-cobalt alloy nanowires prepared by electrospinning as oxygen reduction catalyst, Nano Energy 10: 135-143, (2014)

[29] Amirinejad M., Rowshanzamir S., Eikani M. H., "Effects of operating parameters on performance of a proton exchange membrane fuel cell", Journal of Power Sources 161: 872-875, (2006)

[30] Hakenjos A., Muanter H., Wittstadt U., Hebliy C., "A PEM fuel cell for combined measurement of current and temperature distribution and flow field flooding", Journal of Power Sources 131: 213-216, (2004)

[31] Arif M., Jacobson D. L., Hussey D. S., "Neutron imaging study of the water transport in operating fuel cells", FY 2012 Annual Progress Report, DOE Hydrogen and Fuel Cells Program: 37-42, (2012)

[32] Owejan J. P., Mench M., Hickner M., Kandlikar S., Trabold T., Gagliardo J., Kongkanand A., Gu W., Nicotera 
P., "Investigation of micro- and macro-scale transport processes for improved fuel cell performance", FY 2011 Annual Progress Report, DOE Hydrogen and Fuel Cells Program: 827-832, (2011)

[33] Giurgeaa S., Tirnovanb R., Hissela D., Outbibc R. 2013. An analysis of fluidic voltage statistical correlation for a diagnosis of PEM fuel cell flooding, International Journal of Hydrogen Energy 38 (11): 4689-4696, (2013)

[34] Rezaee V., Houshmand A., "Energy and exergy analysis of a combined power generation system using PEM fuel cell and Kalina Cycle System 11", Periodica Polytechnica Chemical Engineering 60 (2): 98-105, (2016)

[35] Gimba I. D., Abdulkareem A. S., Jimoh A., Afolabi A. S., "Theoretical energy and exergy analyses of proton exchange membrean fuel cell by computer simulation”, Journal of Applied Chemistry Volume 2016: 1-15, (2016)

[36] Haghighi M., Sharifhassan F., "Exergy analysis and optimization of a high temperature proton exchange membrane fuel cell using genetic algorithm", Case Studies in Thermal Engineering 8: 207-217, (2016)

[37] Pragma Industries USB Eload yaz1lım1, (2016).

[38] Dincer I., Rosen M. A., "Exergy. 2nd ed. Chapter 15", Elsevier, Oxford, ISBN 978-0-08-097089-9, (2013)

[39] Ahmadi M. H., Mohammadi A., Pourfayaz F., Mehrpooya M., Bidi M., Valero A., Uson S., "Thermodynamic analysis and optimization of a waste heat recovery system for proton exchange membrane fuel cell using transcritical carbon dioxide cycle and cold energy of liquefied natural gas", Journal of Natural Gas Science and Engineering 34: 428-438, (2016)

[40] Zhang X., Guo J., Chen J., "The parametric optimum analysis of a proton exchange membrane (PEM) fuel cell and its load matching", Energy 35: 5294-5299, (2010)

[41] Larmine J., Dicks A., "Full cell systems explained", Second Edition, John Wiley \& Sons Ltd., Chester, ISBN 0-470-84857-X, (2003)

[42] Purnima P., Jayanti S., "A high-efficiency, auto-thermal system for on board hydrogen production for low temperature PEM fuel cells using dual reforming of ethanol", International of Hydrogen Energy 41: 1380013810, (2016)

[43] Tsai S.W., Chen Y.S, "A mathematical model to study the energy efficiency of a proton exchange membrane fuel cell with a dead-ended anode", Applied Energy 188: 151-159, (2017)

[44] Ferrero D., Santarelli M., "Investigation of a novel concept for hydrogen production by PEM water electrolysis integrated with multi-junction solar cells", Energy Conversion and Management 148: 16-29, (2017)

[45] Salemme L., Menna L., Simeone M., "Calculation of the energy efficiency of fuel processor e PEM (proton exchange membrane) fuel cell systems from fuel elementar composition and heating value", Energy 57: 368 $374,(2013)$ 